\title{
Terrorism and governance strategies in Brussels
}

\author{
Abstract \\ In 2013, we reported on the reform process in Belgium in Fyfe, Terpstra and Tops \\ Centralizing Forces. ${ }^{1}$ On March 22, 2016, Belgium was confronted with the most dramatic \\ act of terrorism in its history. In this article, we sketch the consequences of these events on \\ the police system and to what extent these events have transformed the community-oriented \\ policing (COP) philosophy on which the police reform of 1998 was based.
}

\author{
Volume 6 Issue I - 2018

\section{Elke Devroe,' Paul Ponsaers²} \\ 'Institute of Security and Global Affairs (ISGA), Faculty \\ of Governance and Global Affairs, University Leiden, The \\ Netherlands \\ 2Department of Criminal Law, Criminology and Social Law, \\ Ghent University, Belgium
}

Correspondence: Elke Devroe,Associate Professor, Institute of Security and Global Affairs (ISGA), Faculty of Governance and Global Affairs, University Leiden, The Netherlands, Email e.devroe@fgga.leidenuniv.nl

Received: August 14, 2017| Published: January 18, 2018

\section{Introduction}

In 1998, the Belgian police system was fundamentally reformed by integrating three kinds of police service into a new structure. The three former police agencies were

a. The 589 municipal police forces,

b. The National Gendarmerie, and

c. The judicial police at the public prosecutor's office, which were reorganised into one integrated police service, structured at two levels (Figure 1).

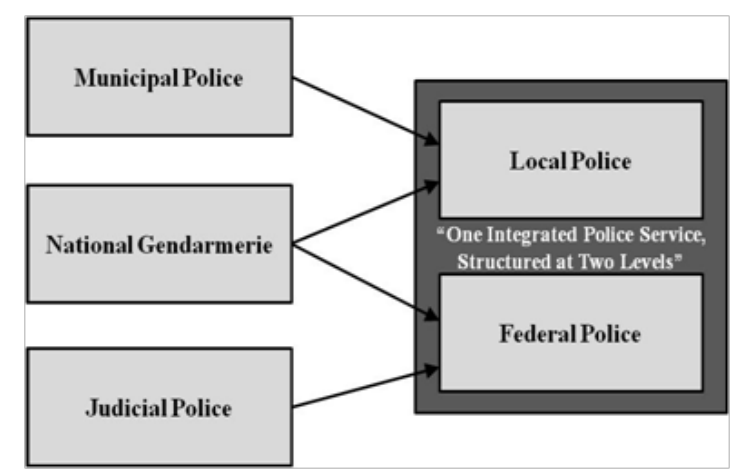

Figure I Belgian Police reform in 1998.

This means that two different kinds of police agencies were created (the federal and local police), which were integrated by means of functional instruments (e.g., a common planning cycle, a shared educational programme, the same databases, etc.). The federal component of the system was designated as being responsible for supra-local and complex forms of public disorder and crime, under the supervision of the minister of internal affairs and of the minister of justice. The local component was no longer implemented on the scale of the 589 municipalities, but on so-called 'zones', which lowered the number back to 196 'zonal' forces. In Table 1 the total capacity of local and federal police personnel is shown per 31/12/2013. Table 1 illustrates that the local component significantly outnumbers the federal component in terms of capacity. At implementation on
January 1, 2001, 196 zones were formed. Since then, some zones have voluntarily merged together, but in 2017 there are still 189 zones.This reform was fully implemented in 2001. No hierarchical link was introduced between the federal and local levels. ${ }^{2}$ The reform coincided with an impressive international consensus in the academic literature concerning the inadequacy of traditional police models such as a military-bureaucratic model or a crime-fighting model. Belgium adopted the reform of a COP policy on this occasion. We summarise some of the critiques being recognised as important, including one by decision-makers: ${ }^{3}$

a. A huge increase in capacity is not an effective strategy to tackle crime and disorder. The quantitative assumption cannot resolve the necessary qualitative change of 'how to do good policing'.

b. The police cannot prevent crime alone, without the population as the 'eyes and ears' in the neighbourhood. The population is to a large extent the most important partner of the police. Police forces need to be externally oriented and empower the citizenry.

c. The classic tactics of traditional police models are too reactive, as they do not affect the possible causes of crime and disorder.

d. Police strategies are too broadly applied to different problems in the same way ('one size fits all'); we need more 'tailor-made responses'. 4

Table I Total capacity of local and federal police as per 3 I/I2/20I3

\begin{tabular}{llll}
\hline \multicolumn{2}{l}{ Real capacity local police } & \multicolumn{2}{l}{ Real capacity federal police } \\
\hline Police officers & Civilians & Police officers & Civilians \\
\hline 28692 & 6038 & 9103 & 3253 \\
34730 & & 12356 & \\
$74 \%$ & $26 \%$ & \\
47086 & & & \\
\hline
\end{tabular}

All political parties, majority and opposition, pleaded for this police model, as well as parliament and the government. Finally, the adoption of COP was consolidated in a directive distributed by 
the Minister of Internal Affairs in 2003. ${ }^{5}$ The practice of COP was embraced to a large extent by the zonal police forces but was less visibly implemented within the federal police.

\section{The political situation in Belgium}

Belgium is a federal country with three regions, Flanders (Dutch speaking), Wallonia (French speaking) and the Brussels capital region (bilingual). Among other things, the federal government is responsible for security and home affairs and for justice. The current federal government is a coalition of Liberals, Christian Democrats, and Flemish Nationalists (biggest party) and reflects a break with the past. The federal government had previously been dominated by the (French) Social Democrats for 25 years. ${ }^{6}$ Each region has its own government. Flanders has a government with the same coalition as the federal government. In other words, symmetry between the federal and Flemish government is a fact. In the French-speaking part the situation is different. Here the social democrats remain in a dominant political position. In other words, there exists an asymmetry between the federal and regional level. The most complicated political situation can be observed in the Brussels region. ${ }^{7}$ The regional government is led by a social democrat, who is responsible for urban policy and security. The coalition is made up of social democrats, Christian democrats, liberals and a French-language party. Again, there is asymmetry with the federal government.Moreover, the Brussels region is composed of 19 municipalities, each with their own mayor, and each of them with their own political affiliation. There is a strong rivalry between French-speaking liberals and social democrats. At the same time, these 19 municipalities are covered by six different police zones. In sum, the federal structure of the country and the multitude of decisionmaking layers easily leads to political paralysis, as much between linguistic parties as between ideological fractions. ${ }^{8}$

\section{The Brussels bombings}

The terrorist bombings ofMarch 22, 2016 in Brussels were not isolated events. They were part of a chain of events in a terrorist campaign by a French-Belgian terrorist Jihadi network that developed on the axis Paris-Brussels. That explains why the Belgian government's reaction to this campaign started earlier than in March 2016, largely coordinated with the French authorities.

\section{The background}

For a long period, Belgium avoided Jihadi terrorism on its territory. There occurred forms of terrorism, but most of these happened during the $1980 \mathrm{~s} .{ }^{9}{ }^{10}$ Notwithstanding, Brussels has had a long history of active Jihadi recruiters. ${ }^{3}$ The Jihadi campaign in Belgium started with the assault on the Jewish museum in Brussels on May 24, 2014. Four people were killed on that occasion. Later, the investigation into this event will make clear that the French-Algerian gunman was suspected to be a 'returnee' from the Syrian civil war. He recorded a video bearing the flag of the so-called Islamic State in Iraq and Syria (ISIS). In fact, he was the first European volunteer in the Syrian war who committed attacks on his return to Europe. ${ }^{11}$ Only a week after the massacre at the offices of the French satirical magazine, Charlie Hebdo, in Paris on January 7, 2015, the Belgian police carried out an anti-terrorist raid on a Jihadist cell in Verviers on January 15, 2015.Two suspects died in the raid. The Belgian prosecutor's office stated that the raids were an operation against a Jihadist terrorist cell, reportedly believed to have links to ISIS, on the verge of committing a terrorist attack.

The cell was led by a Belgian-Moroccan Islamic terrorist from Molenbeek (Brussels), who had also spent time in Syria. He was the ringleader of a series of coordinated terrorist attacks in Paris that occurred on November 13, 2015. Seven perpetrators died at the scenes of these attacks. The other two were killed five days later during a police raid in Saint-Denis, one of whom was the ringleader mentioned above. One terrorist escaped and fled to Brussels: Salah Abdeslam, a Belgium-born French national of Moroccan descent. ISIS claimed responsibility for the attacks. ${ }^{12}$ Belgium tightened security along its border with France immediately after the attacks of November 13, 2015, and increased security checks for people arriving from France. The Belgian government imposed a security lockdown on Brussels, including the closure of shops, schools, and public transportation, because of information about potential terrorist attacks in the wake of the series of coordinated attacks in Paris. ${ }^{13}$ After four months on the run, Salah Abdeslam was apprehended during a police raid in Molenbeek, on March 19, 2016. ${ }^{14}$ In Figure 2 a time-line to the terrorist attacks occurred between 2014 and 2016, both in France and in Belgium, is introduced.

November 13, 2015 March 22, 2016

Assault Paris Assault Brussels

Assault Paris

Charlie Hebdo

museum Brussels

Bataclan
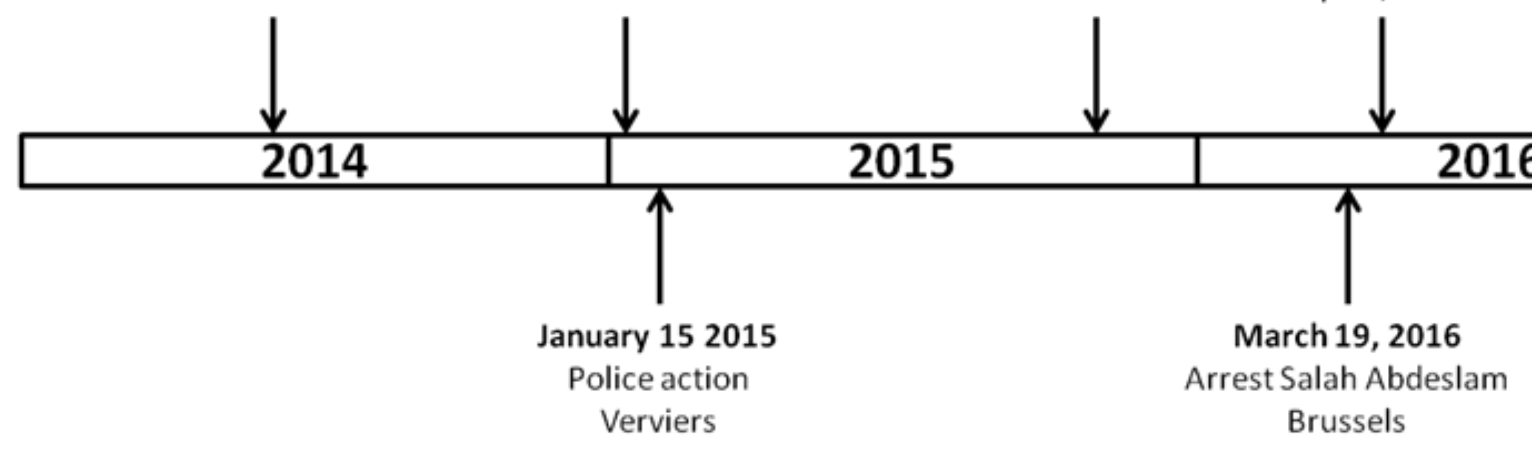

2016

Figure 2 Time-line of related events 20I4-20I6. 
Before 2014 (the assault in the Jewish museum in Brussels) Belgium did not know any terroristic attacks and radicalisation was not yet a political priority. The policy attention and the expansion of police and army personnel in the streets, followed this attack as the threat level was set on 'level 3'. This means that from that moment on, radicalisation was a priority for the Belgian government. The Charlie Hebdo terrorist attacks and the joint police operation involving Belgian and French forces, and the Verviers raid, only augmented fear for terrorism and led to different government counterterrorism measures. In first instance we elaborate on the attacks on Brussels Airport and the metro, and we also discuss the other events in this time-line.

\section{Two suicide attacks on Brussels airport and the metro}

Only a few days later, in the morning of March 22, 2016, two coordinated suicide attacks occurred in Brussels. The first attack was at the national airport (Zaventem), where two nail bombs exploded in the departure hall. The second attack occurred at Maalbeek metro station, located near the European Commission headquarters in the centre of Brussels..$^{15}$ In total, 35 people were killed-32 civilians and three suicide bombers ${ }^{16}$ - while over 300 civilians were injured, 62 critically. Responsibility for the Brussels attacks was claimed by ISIS referring to the fact that Belgium was targeted as 'a country participating in the international coalition against the Islamic State'. ${ }^{17}$ The Brussels bombings were committed by two commandos and five Jihadis. Three of them died during the assaults; two decided not to ignite their explosives and were arrested.

The Brussels bombings resulted in compensations to the victims for a total amount of 322 million euros, according to the Belgian government. They also had to invest 2.3 billion Euros in reconstructing and repairing buildings. The total economic damage as a consequence of the attacks was estimated at 4.47 billion euro. ${ }^{18} \mathrm{After}$ the bombings, Belgium found itself subjected to a barrage of international criticisms that focused on its allegedly weak security policies and complex institutional structure. Belgium-bashers labelled the country a 'failed state' ${ }^{19}$ and a 'Jihadi rear base', ${ }^{20}$ while its intelligence services were supposedly 'shitty tradecraft'. ${ }^{21}$ These accusations were largely exaggerated. ${ }^{22}$ They were also rebuffed by more nuanced studies, and by many testimonies to the parliamentary enquiry commission set up after the Brussels attacks. ${ }^{23}$

\section{Government responses}

In response to the $9 / 11$ massacre, the Coordination Unit for Threat Assessment (CUTA) was installed in July 2006. All the relevant Belgian counterterrorist stakeholders operate together in CUTA, ${ }^{24}$ coordinating the police and intelligence services and assessing to what extent Belgium is vulnerable to terrorist and extremist threats. Everyone agrees today that more needs to be done, and more efficiently, to cope with the challenges of terrorism and radicalization in Belgium. Nevertheless, a lot has been accomplished since the Brussels attacks. In 2015, 26 of 30 measures announced by the government were either implemented or continuing to be implemented. ${ }^{25}$ The legal counterterrorism framework has been broadened, while the financial and human resources available to security services have been bolstered. Beyond law enforcement measures, local risk management has also been strengthened.

\section{The response to the Charlie Hebdo attacks}

As a consequence of the Charlie Hebdo terrorist attacks and the joint police operation involving Belgian and French forces, and the
Verviers raid, the federal government decided on a package of 12 counterterrorism measures, released in January 2015. ${ }^{26}$ A number of these measures concern the enforcement of criminal law. It is worth noting that three new terrorism-related offences had already been added to the criminal code in 2013, concerning recruitment, provision and acquisition of terrorist training and public incitement to commit terrorist offences. Other measures, more directed towards the organisation of counterterrorism, included the following: ${ }^{27}$

a) The establishment of a National Security Council, ${ }^{1}$ which determines general policy concerning intelligence and security, coordinates the policy, and sets the priorities of intelligence and security services. The council is chaired by the federal prime minister.

b) This council is also coordinates actions against the financing of terrorism and the proliferation of weapons of mass destruction. Legally established mechanisms to identify persons involved in the financing of terrorism were activated and assets were frozen. ${ }^{2}$

c) A new directive was launched ${ }^{3}$ concerning the follow-up of 'foreign fighters' who are living in Belgium, especially by the municipal administration. Mayors were requested to establish local cells for integral security (LCIS). ${ }^{4}$

d) Exchanges of information between the authorities and the administrative and judicial services were optimised. A so-called 'dynamic' (continuously updated) foreign fighters database became operational, which enabling the tracking of these people and their activities 5 .

e) A national taskforce prepared a new confidential plan against radicalisation, which determines which administrative and judicial measures can be taken at preventive, proactive and reactive level. ${ }^{6}$

f) The fight against radicalism in prisons by the Minister of Justice.

g) The calling-in of the Belgian army for specific monitoring missions. ${ }^{8}$

h) Strengthening the capacity of the State Security Service and transfer of VIP protection to the federal police.

\section{The response to the Bataclan attacks}

A second set of 18 measures was announced later on, in the days following the coordinated terrorist attacks in Paris on November 13, 2015. The measures included the following.

1. Increasing the security budget; $€ 400$ million for security and the fight against terrorism became available. The following measures were presented by the government (Ponsaers \& Devroe, 2017).

\footnotetext{
${ }^{1}$ Royal Decree, January 28, 2015.

${ }^{2}$ oyal Decree, December 28, 2006 concerning specific limiting measures against certain persons in the struggle against the financing of terrorism.

${ }^{3}$ Directive of August 21, 2015.

${ }^{4}$ The LCISs regularly gather together all key local stakeholders, such as the mayor, head of local police, prevention officers and social workers. Regional platforms and 'mobile teams' were also created to facilitate the exchange of good practices between municipalities, while multidisciplinary support centres were launched to help citizens confronted with radicalisation.

${ }^{5}$ Second Law on Terrorism of April 27, 2016. Royal Decree of July 21, 2016. ${ }^{6}$ Established May 29, 2015.

${ }^{7}$ Parliamentary question of August 10, 2015 to the prime minister.

${ }^{8}$ The use of the military for security duties has been practised since January 2015. This was demonstrated in the 'Brussels lockdown' of November 21-25, 2015 and increased after the Brussels terrorist bombings in March 2016.
} 
2. The reinforcement of police controls at the borders.

3. The deployment of 520 soldiers to reinforce security. This decision was systematically extended by the council of ministers.

4. The introduction of new technologies for the intelligence services (e.g. voice recognition, expansion of wiretapping including arms trafficking). ${ }^{9}$

5. The government wants to extend the duration of administrative detention ${ }^{10}$ from 24 hours to 72 hours in terrorism related cases. ${ }^{11}$

6. House searches 24 hours a day for terrorist offences. Before it was forbidden to perform searches between 21:00 (9 pm) and 05:00 (5 am)..$^{12}$

7. The measure concerning 'foreign fighters' targets the 'returnees'. In the case of 'returnees', the Belgian government has declared it wants to systematically deprive them of their liberty upon their return to Belgium. ${ }^{13}$ Today, the decision to deprive someone of his liberty remains a decision of the judge, and is not an administrative measure or a systematic practice. It is the judge who can decide whether it is a terrorist or war-related crime which can be convicted according to Belgian law. Furthermore, the question is raised as to whether prison is the best place to reintegrate.

8. For those who are more generally registered as 'threats' to national security and who have not necessarily been implicated in 'foreign fighting', the government wants to place them under electronic surveillance. ${ }^{14}$

9. Anticipating the establishment at European level of a passenger name record (PNR), a decision was made to already create such a record at Belgian national level. ${ }^{15}$

10. Screening of all hate preachers in order to place them under house arrest, deprive them of their liberty or to expel them. In practice, today in individual cases, it is again the judge who will decide whether or not detention can be used, according to the criminal law. Also, forms of so-called 'house arrest' are at his discretion. In these cases, the Belgian policy goes less far than France or the Netherlands, for example. ${ }^{16}$

${ }^{9}$ These measures imply the revision of the criminal law. The council of minister prepared a proposal that was discussed for the first time within parliament A second reading was requested recently by the Green Party because of 'the absence of sufficient control mechanisms'.

${ }^{10}$ The so-called gardeàvue in the framework of maintenance of public order by the police, and not for offenders who are indicted for specific crimes by the magistrate.

${ }^{11}$ This measure implies revision of the Constitution and consequently a twothirds majority in Parliament. This proposal leads to discussion between government parties and the opposition, who fears that this extension will also be applied to other forms of crime. For a critique on this proposal, see Human Rights Watch (2016).

${ }^{12}$ Law of April 27, 2016 concerning additional measures against terrorism (art. 3).

${ }^{13}$ The particular question of the relationship between prison and radicalisation is also on the radar in Belgium. Authorities have opened prison sections specifically dedicated to housing radicalised detainees to keep them from spreading their ideas to others.

${ }^{14} \mathrm{~A}$ 'foreign fighters' task force and a 'returnees platform' have also been created.

${ }^{15}$ This database is used to centralise data initially for passengers using flights, and at a later stage will include high-speed trains and boats, in order to identify potential 'red flags'.

${ }^{16}$ Hate preachers who have another nationality, even if they are born in Belgium and are not condemned, can be expelled to the country of their nationality. This is a new administrative measure which can be taken in the framework of the migration and asylum laws.
11. Dismantling unrecognised places of worship which propagate Jihadism.

12. End of anonymity for pre-paid cards.

13. The execution of the 'MolenbeekPlan' (renamed later 'canal plan'), conceived by the Belgian Ministry of Home Affairs, which focuses on eight municipalities in Brussels and surrounding areas, intending to monitor those localities perceived as vulnerable to radicalisation.

14. The reinforcement of screening before access to 'sensitive jobs'.

15. Extension of the network of cameras recognizing license plates.

16. Closing down websites which preach hate.

17. Evaluation in order to adapt legislations linked to the 'state of emergency' (the possibility for temporary and exceptional measures to ensure public safety). The 'state of emergency' (as in France or the Netherlands) cannot be declared in Belgium at the moment because a clear legal framework is absent ${ }^{17}$.

\section{Participation in the international fight against ISIS.}

It is striking that no solution was installed centralising the fragmented police capacity (six zones) and organising one command (one mayor) installing a more structural solution to the police problems in Brussels with its 19 different municipalities, each with their own mayor.

\section{The response by civil society}

A number of organisations have reacted to the governmental measures taken. One of them is Amnesty International, ${ }^{28}$ which advocated for caution in the initiatives, warning that measures should not threat or limit civil rights. AI advises the government to assess in first instance the existing instruments against terrorism before implementing new ones. New offences should be tested by means of the principles of legality and proportionality. Specific attention is paid to the risk of penalising intentions without the actual criminal behaviour. Furthermore, AI warns against discriminatory or arbitrary measures and insists on a severe policy against the illegal trade of weapons. In a subsequent report, $\mathrm{AI}$ reacts to the international political situation in Europe. ${ }^{29}$ The second organisation reacting on these governmental response is Human Rights Watch. This organisationobserves that at least six of the government's newly adopted laws and regulations threaten fundamental rights. A law allowing the stripping of Belgian citizenship from dual nationals could create perceptions of 'secondclass' citizens based on their ethnicity and religion. An amendment to the penal code that criminalises the act of leaving Belgium 'with terrorist intent' contains vague language that could restrict the travel of people for whom there is no evidence that they intend to commit or support extremist armed acts abroad. ${ }^{30}$

In third instance, The League for Human Rights also expresses its hesitations concerning the new measures. The organisation calls them 'either already existing, or completely pointless, or not applicable'. According to them, the detention of 'foreign fighters' is possible as long as this decision is made by a judge, while it pleads strongly against administrative detention. The use of electronic surveillance against radicalised persons is not possible. Only an independent judge can take this decision if there is a crime committed. The League is also not in favour of the prolongation of administrative arrest. The

${ }^{17} \mathrm{~A}$ state of emergency is determined in time. During this period, specific measures can be taken to counter imminent problems. After this period, these measures are cancelled and government returns to 'normality'. Some majority parties are pleading for this. For a critique, see Amnesty International (2017). 
gathering of more information is criticised. Most of the people involved in the Paris attacks were known by the security services. More focused controls should be introduced instead of considering a priori the whole civil population as suspect. ${ }^{31}$

\section{The lack of co-ordination of the municipal initiative}

The federal specialised anti-terror section in Brussels (the socalled 'DR3') only invests 6.8 percent of its capacity (seven people) in preventive missions because of a lack of personnel. ${ }^{32}$ It is clear that prevention is primarily a local task. But, as a consequence of the lack of a coordinated prevention policy, today one municipality has a deradicalisation policy but not a single foreign terrorist fighter, while another municipality has several fighters, but no policy. In Flanders, the problem of radicalisation is concentrated in Antwerp and Vilvoorde, but about 40 other municipalities alsohave problems. Only 10 of these municipalities are managing to follow up 'returnees'. Seven of them started doing so only recently. In contrast, it is striking that there are also some municipalities which are not confronted with Syria fighters, but nevertheless still have specific programmes and de-radicalisation officials. In fact, in several municipalities nobody knows exactly whether or not there are 'returnees' on municipal territory. ${ }^{33}$ For example, let's have a closer look at the municipality of Molenbeek, which officially has 95,576 inhabitants and an average age of 34 years, all living in an area of less than six $\mathrm{km}^{2}$.

Certain neighbourhoods have a density of between 30,000-36,000 inhabitants per $\mathrm{km}^{2} \cdot{ }^{34}$ Between 1995 and 2016, the official population grew from 68,000 to 95,000 inhabitants, without taking into account the 5,000 to 9,000 non-documented residents. This explosive growth is the consequence of a high birth rate and low mortality rate (because of the high proportion of young migrants) and of an important influx of new migrants. ${ }^{35}$ Furthermore, the municipality has a strikingly mobile population. In 2012 we observed that the turnover in the population was so significant that even beat officers were not able to monitor precisely who was living where. Domicile controls proved to be almost impossible and as a consequence were immediately outdated. ${ }^{36}$

According to the police chief of the police zone Brussels-West, in which the municipality of Molenbeek is included, the local police force has to accommodate newcomers in houses officially declared 'uninhabitable' because there is no alternative housing. Furthermore, he claims that there are not enough schools to keep up with the rapid population growth. ${ }^{37}$ The drop-out rate of youngsters in schools is significant and the population is characterised by a low educational level. The unemployment rate is also tremendously high. Among youngsters this rate is one of the highest in Europe. Half of young inhabitants between 18 and 25 years are unemployed, even if they have a high-school diploma. ${ }^{38}$ The chief of police of Brussels-West stresses the fact that there are many associations working in Molenbeek, but he claims there is hardly any consultation between these organisations themselves or with the zonal police. Some of the initiatives are supported by the Brussels region, others by the Flemish community or the federal government. All of them are doing similar things, but there is an obvious lack of coordination. To a large extent we can explain this situation as a consequence of the structural position of this municipality within the Brussels capital region. In other words, the combined promise of COP and Intelligence Led Policing (ILP) is surely not satisfied. ${ }^{39}$

This kind of urban environment is described in the classic study of Samson et al. ${ }^{40}$ as a place par excellence for the development of adolescent crime careers. This risk increases with the presence of recruiters, such as Khalid Zerkani, who lured in youngsters with a criminal background and pushed them further along this pathway. He looked for them not in mosques, but in drug-dealing pubs, with an apocalyptic story promising a new and better life in Syria. These young Muslims were attracted by the dangerous cocktail of risky delinquency and romanticised heroism. ${ }^{41}$ It is in this context that the local police of Molenbeek have to function, not only to tackle the demon of terrorism, but to avoid young inhabitants developing delinquent careers in the first place and becoming outlaws who have nothing more to lose.

\section{The federal 'Canal Plan' and the regional security plan}

As mentioned already, in January 2016 the Belgian federal government came up with a swift answer to the events of November 2015in Paris, the Federal Action Plan against Violent Extremism and Terrorism. The government translated the problem of terrorism into a quantitative capacity problem. By 2019 , the government wants to create 1,000 new police posts joining in the struggle against terrorism. A specific part of this action plan is the so-called 'canal plan' of the Minister of Home Affairs, Jan Jambon. This plan envisions 300 new vacancies in the Canal Zone in Brussels, including the Brussels municipalities of Molenbeek, Vilvoorde, Anderlecht, Koekelberg, Laken, Schaarbeek, Sint-Gillis, and Sint-Joost-ten-Node. It is remarkable that the federal minister formulated this plan, while the law on the integrated police stipulates that local plans are to be formulated by local decision-makers. But it is all the more remarkable that the plan supposes an alliance between mayors of specific municipalities and not between police zones. The Dutch-speaking, Flemish nationalist and right-wing minister,Jambon, must trust now in the goodwill of many stakeholders, including a number of Frenchspeaking left-wing mayors, for the realisation of the plan. Molenbeek and Vilvoorde are considered in the plan as the most urgent targets. From February 1, 2016 onwards, these municipalities have received additional capacity from the federal police.

The chief of police of Brussels-West commented on the plan, stating that this canal plan does not change the structural shortage in his force, because the budget for the force did not evolve together with population growth. In fact, the Brussel-West force has the lowest budget of the Brussels capital region. In addition to the federal measures, the Brussels region took its own initiative, based on its new competences brought by the sixth Belgian state reform in July 2012. Among other goals, this new structure foresees financial contributions for regional efforts concerning security. ${ }^{42}$

As a consequence of that, the minister-president of the Brussels region, Rudi Vervoort, responsible for security since July 1, 2014, presented a plan together with the mayors of Brussels city, Schaerbeek, Anderlecht and Molenbeek, simultaneously with Minister of Interior Jambon's development of his 'canal plan'. In this regional plan, a global and integrated approach has been announced for the problem of radicalisation, concentrating on problems of education, youth care, employment, social housing and social cohesion. It is striking that neither plan (the federal 'canal plan' of the interior minister nor that of the Brussels region) refers to the other. Instead of a real integrated local security policy, we observe a significant decoupling of the federal police strategy and the regional social policy. Especially in Brussels, these tensions lead to harsh debate. At the federal level and in Flanders, counterterrorism is dominated by severe law enforcement and risk management strategies, while in Wallonia and Brussels the tendency is to focus on social policy and prevention. ${ }^{23}$ 


\section{Conclusion}

At this stage, it may be too early to draw peremptory conclusions. This being said, it is possible to conduct a preliminary analysis of the expected efficiency of these governance measures. We observed for a period a solid reactive law enforcement strategy while a preventive social strategy was largely neglected. A much more active preventive role of the administrative local authority-more specifically of the mayors-was absent. In essence, the judiciary had monopolised the problem and the administrative and preventive approach was considered in fact as less urgent. This is the corollary of the policy concept politicians have of the real nature of police work-namely 'tackling crime', a concept that seems attractive in times of austerity. But police efforts can hardly influence crime, because the causes of crime are beyond the sphere of influence of the police and can only be countered by means of a mature and concrete local integral security policy. As Peter Manning ${ }^{43}$ explained much earlier (1977), the mandate of the police is fragile and vulnerable, and police personnel should be aware that they personify a promise they can never keep.

As a consequence of this, certain aspects relating to the centrality of the law enforcement approach must be reconsidered. In Belgium, as opposed to several neighbouring countries, most terrorist files are transmitted very rapidly to the judicial authorities, with practical consequences for the manner in which investigations are conducted, as well as the type of information collected. It is argued that local stakeholders should play a more active role in the prevention of terrorism, ahead of the transmission of files to the judiciary authorities. ${ }^{44}$ After explaining the complex constitutional setting in Brussels, where 19 municipalities and six police zones in two different languages try to combat terrorism, one can wonder why not simply reunite these forces into one police corps led by one mayor, under the supervision of the Minister of Interior, as in Berlin or Paris. ${ }^{45}$ Central command would be a logical solution leading to efficiency, cost reduction and more capacity, facilitating data exchange and partnership. Of course, this solution was proposed by the federal Dutch-speaking Minister of Interior, followed by a fierce 'no' from French-speaking politicians in Brussels. It is obvious that the Belgian constitutional context leading to fragmentation in linguistic and political objectives hinders an efficiency driven response in police (re)organisation.

\section{Acknowledgments}

None.

\section{Conflicts of interest}

Authors declare that there are no conflicts of interest.

\section{References}

1. Devroe E, Ponsaers P. Reforming the Belgian police system between central and local. In: Fyfe NR, Terpstra J, editors. Centralizing Forces? The Netherlands: Comparative Perspectives on Contemporary Police Reform in Northern and Western Europe, Boom Legal Publishers/Eleven; 2013. p. 77-98.

2. Van Branteghem JM, Van de Sompel R, Ponsaers P, et al. Pillars of community policing in Belgium. In: Bruggeman W, Van Branteghem JM, editors. USA: Towards an Excellent Police Function; 2007. p. 15-36.

3. Ponsaers P, Devroe E. How integrated is local prevention of radicalisation and terrorism? In: Renard T, editor. Counterterrorism in Belgium. USA: Key Challenges and Policy Options, Egmont Paper no.89; 2016. p. 23-33.
4. Verhage A, Ponsaers P. Impacts of community oriented policing. In: Bruinsma G, Weisburd D, editors. Encyclopedia of Criminology and Criminal Justice (ECCJ). 2013;2430-2435.

5. Duquesne A, Verwilghen M. Directive CPI of the 25th of May 2003 concerning community policing; definition of the Belgian interpretation of the integrated police service, structured at two levels, B.S. 09-072003, Attachment to the circular letter. In: Van de Sompel R, Ponsaers P, editors. USA: The pillars of community-oriented police care in Belgium. 2003. p. 66.

6. Devroe E. A swelling culture of control: The genesis and application of the incivilities law in Belgium. In: Ponsaers P, editor. Social Analysis of Security: Financial, Economic and Ecological Crime, Crime (In) security and Distrust, Public and Private Policing. Eleven international Publishing. 2012;355-362.

7. Ponsaers P, Devroe E. A new structure for the Brussels police? Vigiles, Review of Police Law. 2016;42(2):51-56.

8. Ponsaers P, Devroe E. Molenbeek (March 2016) after Paris (November 2016). The canal plan and the insidious privatization. Cahiers Police Studies. 2016;39(2):213-236.

9. Vander Velpen J. De CCC. Het terrorisme en de staat (The CCC. Terrorism and the state), Europe. 1986.

10. Ponsaers P, Dupont G. De Bende: Een documentaire (The Gang: A documentary), Europe. 1988.

11. Bartunek RJ. Police hunt Brussels Jewish Museum gunman. France tightens security. 2014.

12. Hamaide de la S. Timeline of Paris attacks according to public prosecutor. 2015 .

13. Tutt P, Pramuk J. Brussels lockdown: highest alert level maintained. USA. 2015.

14. Rubin AJ. Radicalization of a promising student turned bomb maker in Brussels. Europe. 2016.

15. Lasoen K. Indications and warning in Belgium: Brussels is not Delphi. Journal of Strategic Studies. 2017;40(7):927-962.

16. Holehouse M. El Bakraoui brothers: who are the suicide bombers Khalid and Brahim behind the Brussels attacks? USA: The Telegraph; 2016.

17. Hjelmgaard K, Reuter D, Bacon J. Islamic State claims responsibility for Brussels attack that killed dozens. USA Tpday; 2016.

18. Andersen L. Brussels attacks: attacks cost 322 million euros in compensation and damages. USA: The Brussels Times; 2016.

19. King T. Belgium is a failed state: Brussels' nest of radicalism is just one of the failings of a divided, dysfunctional country. Politico, Europe. 2015.

20. Papirblat. The rear base of Jihadi terror: A quiet Brussels suburb. USA: Haaretz; 2015.

21. Weiss M, Youssef NA, De Visser N, et al. US officials bash "shitty" Belgian Security Forces. USA: Daily Beast; 2016.

22. Renard T. Why Belgium is not Europe's Jihadi base: Belgium bashing is unfounded and only dilutes our collective sense of responsibility. Europe: Politico; 2016.

23. Renard T. Counterterrorism in Belgium: Key Challenges and Policy Options, Egmont Paper no.89. 2016.

24. Vercauteren G. International Conference on National and International Coordination in Counterterrorism. The Belgiancoordination Unit for Threat Analysis. 2013;1-11. 
25. Seron V, André S. 30 measures against terrorism: penal populism between expected efficiency and potential collateral damage. In: Renard T, editor. USA: Counterterrorism in Belgium: Key Challenges and Policy Options, Egmont; 2016. p. 10-22.

26. Blyth D. Government introduces 12 anti-terrorist measures. USA Flanders Today; 2015.

27. Ponsaers P, Devroe E. The Brussels Bombings-Striking a Balance Between Law Enforcement and Risk Management. In: Kellner AM, editor. Democracy and Terrorism-Experiences in Coping with Terror Attacks-Case Studies from Belgium, France, Israel and Norway, Friedrich Ebert Stiftung, International Policy Analysis. 2017. p. 5-14.

28. Security \& human rights: Measures against terrorism and radicalization (Security \& Human Rights: Measures against Terrorism and Radicalization). Europe: Amnesty International Flanders; 2015.

29. Dangerously Disproportionate: The ever-expanding national security state in Europe. Europe: Amnesty International; 2017.

30. Grounds for concern-Belgium's counterterror responses to the Paris and Brussels attacks. Europe: Human Rights Watch; 2016.

31. Belga. Human Rights League files measures against terrorism: Useless or inapplicable. Europe: De Morgan; 2015.

32. Doraene JP. Terrorism: the report that dissects the real reasons for the police failure. Europe: Le Vif ; 2015.

33. Vergauwen E, Dhondt R. Each municipality has its own (non-) policy against Syria fighters. 2016.

34. Leman J. The social issues in Molenbeek and the violent. Europe: Cahier Police Studies; 2017. p.1-12.

35. Corijn E. Brussels, a cosmopolitan city in the making (Brussels, becoming a city becoming a cosmopolitan region). In: van de Bossche $\mathrm{M}$, Lleshi B, editors. Europe: Identity and interculturality: Identity construction among young people in Brussels, VUB Press; 2010.
36. Liedenbaum C, Descheemaeker L, Easton M, et al. The Neighborhood behind the Collision: An Investigation into Neighborhoods in the Netherlands and Belgium with serious Disruptions of the Order (the neighborhood after the clash: a study into neighborhoods in the Netherlands and Belgium with serious disturbances of public order). Series of police studies. 2013;(7):1-268.

37. Schoofs N. I have too few agents who speak Arabic. I don't have enough officers that speak Arabic, The time. 2016

38. Leman J. Laag-Molem, Kuregem Kuren and Buitenlandse Neuren. Low Molem, caprices from Kuregem and foreign neighbors. Cahiers Police Studies. 2010;2:101-120.

39. Ponsaers P. An unbridgeable gap grows between word and deed. Between words and acts grow an unbridgeable split. In: Bruggeman W, Hardyns W, editors. Radicalism and Terrorism, From Theory to Practice. Series of Safety Studies. 2016;15:135-144.

40. Sampson RJ, Groves WB. Community structure and crime: Testing socialdisorganization theory. American journal of sociology. 1989;94(4):774 802 .

41. Khosrokhavar F. Inside Jihadism: Understanding Jihadi Movements Worldwide. USA: Paradigm Publishers. 2019.

42. Meerschaut K, De Hert P. An integral safety policy at the regional level. A closer look at the Brussels Region (An integral security policy at the regional level. A closer look at the Brussels region). Europe: Legal \& Doctrine; 2008. p. 542-576.

43. Manning PK. Police work: The social organization of policing. USA: MIT Press; 1977. p. 1-372.

44. Devroe E, Edwards A, Ponsaers P. Policing European Metropolises: The Politics of Security in City-Regions. USA: Routledge; 2017. p. 1-342.

45. Devroe E, Ponsaers P. Radicalization in Molenbeek, Belgian two-track policy prevents integrated approach. Radicalization in Molenbeek, Belgian two-track policy with an integrated approach. Process. 2017;96(1):40-58. 